\title{
MOLECULAR CHARACTERIZATION OF GENE 16S rRNA MICRO SYMBIONTS IN SPONGE AT MELAWAI BEACH, EAST KALIMANTAN
}

\author{
Ismail Marzuki*, Alfian Noor, Nursiah La Nafie , M. Natsir Djide ${ }^{1}$ \\ Department of Chemistry, Faculty of Mathematics and Natural Sciences, and ${ }^{1}$ Faculty of Pharmacy, \\ Hasanuddin University \\ *Contact : ismailmz3773@gmail.com
}

\begin{abstract}
Molecular characterization studies have been conducted 16S rRNA gene micro symbiont of sponge origin Melawai Beach, Balikpapan in East Kalimantan. Objective analysis of histomorphological research, isolation-purification, molecular characterization of micro-symbiont genes in order to search symbiont bacteria that can live in extreme environments contaminated hydrocarbon waste. The research method that morphological identification, isolation-purification and molecular characterization of the 16S rRNA gene with Chain Reaction Polymerization method. The results of histo-morphological analysis concluded sponge samples with species of Callyspongia sp. Isolation and purification mikro symbionts of sponge obtained 2 (two) isolates. Characteristics of Isolates 1; spherical shape, colonize and creamy, while isolates 2; jagged shape, oval and white colonies. Molecular characterization of the 16S rRNA gene by PCR, Bacillus subtilis strain BAB-684 identification for isolates one is the number of nucleotide pairs reached $899 \mathrm{bp}$ and the degree of similarity in GenBank reached $89 \%$ homologous, while the second is a Bacillus flexus strain PHCDB20 isolates the number reached 950 bp nucleotide pairs with the degree of similarity in GenBank reached $99 \%$ homologous.
\end{abstract}

Keywords: Callyspongia sp, micro-symbionts, characterization, gene Molecules

\section{INTRODUCTION}

The marine environment has a vital role in human life, not only as a means of transportations, over the sea is a wide variety of organisms living and needed to ensure the survival of organisms, including humans. Many findings mineral deposits of minerals, oil and gas in the sea where the sea adds vital to human life.

Potential contamination of waste petroleum hydrocarbons can occur in almost all lines of petroleum activities ranging from exploration through refining process and potentially generate sludge waste of petroleum (oil sludge), (Aliyanta et al., 2011).

The main components of petroleum contaminants slugde are aliphatic and aromatic hydrocarbons (PAH) are hydrophobic, making it easy to stick to organic material of solid particles formed mikropolutan persistent in the environment. PAHs as toxic substances can damage marine life and human health due to potentially interfere with carcinogenic and mutagenic effects have, (Gan et al., 2009; Wu et al. 2008).

Human responsibility in defending the quality of the marine environment is done by controlling pollution petroleum waste either physics, chemistry or biology has been conducted on an ongoing basis. One of the efforts to address waste oil contaminated environment is the use of microorganisms that can degrade components of toxic hydrocarbons PAHs, (Syakti et al., 2013: Gan et al., 2009).

One of the microorganisms that can degrade hydrocarbons PAHs particularly 
low and high molecular weight are bacteria, (Teng et al., 2010; Gan et al., 2009; Avecedo et al., 2011).

Some marine bacteria known to degrade aromatic hydrocarbon compounds with high toxicity by utilizing components of PAH as a source of carbon and energy source, (Gan et al., 2009; Murniasih et al., 2009), is the dominant type of bacteria Enterobacter sp., Bacillus sp. , Clostridium sp., Pseudomonas sp., Aeromonas sp and Citrobacter sp., (Gan et al., 2009; Crawford in of Yani and Akbar, 2012; Ekpo and Udofia, 2008).

Degrading bacterium Bacillus group component aromatic compounds, such as: $B$ macerans, $B$. mycoides, $B$. megate-rium, $B$. subtilis, B. pumilus, B. thermoleovorans, $B$. gordonae, and B. benzoevorans, (Gan et al., 2009; Zarilla, 1987).

Some of the above mentioned bacteria can be symbiotic with sponges, (Murniasih, 2010; Mahdiyah et al., 2012). Bacteria is one of the microorganisms that are often found in symbiosis with the sponge. It is estimated that up to $40 \%$ biomass several types of sponges prepared by the bacterial community, (Thakur, 2004). Identified several indigenous bacteria can degrade petroleum sludge, (Syakti et al., 2013).

Symbiont microorganisms with sponge has two important roles in biological systems sponge, first as a source of good food by microorganisms symbionts itself or by sponge, both micro sponge symbionts make as host for life and utilize micro sponge simbionnya as a defense in order to adapt and live in the environment extreme (polluted environments), (Steindler et al., 2002; Zarilla, 1987 ).

Sponges are multicellular metazoa animals, which are filter feeder porous, so it becomes a habitat for microorganisms to nesting in the body, (Kozloff, 1990).

Melawai beach Balikpapan including the tides beach, is a tourist destination and culinary visited by many people. Melawai Beach scenery is quite interesting because it is a means to view traffic tankers, cargo and vessels passing the Pelni, this situation happens every day, which contributed an increase in the volume of oil spills, (Jayardana, 2006). The circumstances which encourage the search and identify research sponge that can live in polluted areas are also very possible hydrocarbon presence of micro-symbionts that can detoxify waste toksit properties of hydrocarbons.

The purpose of this research is the search and micro sponge symbionts that can degrade PAHs in particular hydrocarbon waste through histomorphological analysis, isolationpurification and molecular characterization of the 16S rRNA gene micro symbiont of sponge origin Melawai Beach Balikpapan East Kalimantan. The benefits to be achieved from this study are expected to contribute and can provide scientific information about the type of sponge and symbiotic bacteria can live in areas contaminated by waste oil to help reduce the negative impact that the toxic properties of marine life damage can be minimized.

\section{METHODS \\ Material}

Sponges origin Melawai Beach Balikpapan, $\mathrm{CH}_{3} \mathrm{OH}$ pa, sterile sea water, Phosphate Buffer Saline (PBS), Sea Water Complit (SWC), Media NA, marine agar (MA), $25 \%$ glycerol, micro-symbionts sponge isolates, $4 \%$ formalin, Aqubides , $\mathrm{ddH}_{2} \mathrm{O}$, chelex $20 \%$, a pair of universal primary sequences of the $16 \mathrm{~S}$ rRNA gene of E. coli: FP-U1 (5'CCAGCAGCCGCGGTAATACG-3') at nucleo-tides 518-537, and RP-U2 is (5'ATCGG

TACCTTGTTACGACTTC-3')

$(\mathrm{C} / \mathrm{T})$ corresponding to nucleotides 1513-1491, template DNA, Taq DNA polymerase (Perkin-Elmer, Norwalk, Conn), PCR Mix, Triton X-100, Tris, EDTA, $\mathrm{HCl}, \mathrm{KCl}$, $\mathrm{MgCl}_{2}$, paraffin, deoxynucleoside triphosphate, polyacrylamide gel, agarose, Ethidium Bromide.

\section{Instrument}

Scuba, underwater camera, GPS, 
dissectingpan, scalpel, forceps, wattle, plastic bag, ice box, haemositometer, porcelain cup, mortar and pestle, blender, set of glassware, bunsen, analytical balance, hot plate, rubber suction, Whatman, oven, freezer, BOD bottles, thermometers, ose round, effendorf $1.5 \mathrm{~mL}$ tube, vortex shaker, centrifuged $1000 \mathrm{rpm}, 4000 \mathrm{rpm}$ and 10,000 rpm, media spoon, stirrer, compactor container gel, universal $\mathrm{pH}$ paper, salinometer, stop watch, laminary water flow (LAF), autoclove, filter $0.2 \mathrm{~lm}$, PCR machine (Biorad), Bioedit program, MAS100 (Microbio-logical Air Sampler), micropipette, tip filter, gene cycler, gel doc, and electrophoresis.

\section{Time and Place Research}

When the study was conducted in July to December 2014. The research at the Laboratory of Pharmaceutical Microbiology Faculty of Pharmacy, University of Hasanuddin, and Microbiology Laboratory Hasanuddin University Educational Hospital.

\section{Samples and Sampling Location}

Potential sponge samples obtained from petroleum hydrocarbon contaminated area, Melawai Beach Balikpapan in East Kalimantan., (Jayardana, 2006). Sponge samples were taken at four points with code samples A, B, C, D, taken at a depth of 2.7 $m$ with scuba diving technique was held on December 19, 2013

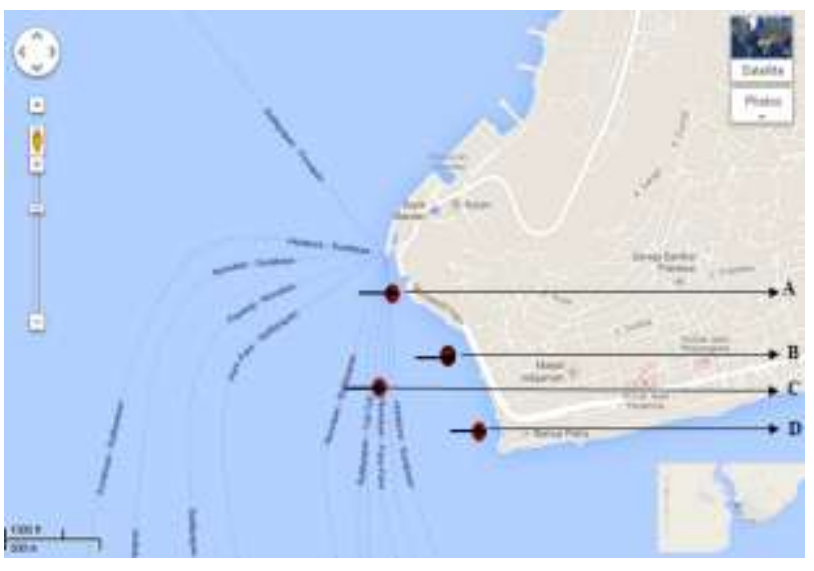

Figure 1. Sampling point sponge of Melawai Beach
After the sponge samples lifted to the surface, immediate photo shoot and taken most of sponge tissue, then put in a $5 \%$ marine broth medium for isolated (direct plating method). Supporting data measured at each sampling point is: the coordinates, temperature, depth, salinity, and $\mathrm{pH}$.

\section{Analysis Method}

The method of analysis is done in three (3) stages of the work, namely: 1) histo-morphological analysis of sponge; 2) isolation and purification of microsymbionts; 3) molecular characterization of the 16S rRNA gene PCR method.

\section{Analysis morphology of the sponge}

Identification of the sponge is done by analyzing the specific characteristics (color, texture, shape, size and depth of sampling. While the histo-morphological analysis of sponge cells under a microscope by MTT assay, assay, (A) Cell Culture Before treatment $24 \mathrm{~h}$ incubation, after 4 hours addition of MTT reagent, (B) control cells, (C) the extract concentration of $960 \mathrm{mg} /$ $\mathrm{mL}$, (D) extract concentration of $7.5 \mathrm{mg} /$ mL, (E) control DMSO, (Hooper, 1997).

\section{Isolation and purification of bacterial symbionts sponge}

Sea sponge that has been identified in the histo-morphological analysis, then taken to be isolated by means of a sponge sample was sprayed on the surface with sterile sea water with every1 ratio of: 5 $\left(\mathrm{cm}^{2}: \mathrm{mL}\right)$ sterile sea water, so that only bacteria with a strong affinity separate. Part mesohyl taken with $\pm 1 \mathrm{x} 1 \mathrm{~cm}$ size, crushed and diluted with Phosphate Buffer Saline (PBS) sterile with a ratio of $1: 1$, (Kim et al., 2006).

Isolation of bacteria using a sterile swab, (Wahl et al., 1994), which is rubbed with a direction on the outer surface of the sponge. Sterile swab was rubbed on the surface of the sample is introduced into the dilution tube containing sterile PBS and divorteks. Dispersed dilution results in a petri dish that already contains media Sea 
Water Complit (SWC) with 1 liter of medium composition consisting of $5 \mathrm{~g} / \mathrm{L}$ bacto peptone, $1 \mathrm{~g} / \mathrm{L}$ yeast extract and 3 $\mathrm{mL} / \mathrm{L}$ glycerol, and incubated at $30{ }^{\circ} \mathrm{C}$ for 24-36 hours, the observed growth of the colony. Each colony morphology observed growing bacteria, such as color, size and shape of the colony. Colonies that grew dominant for isolated and purified separated using the same media.

In the direct plating method, observed colonies that grow after incubation for 1 to 2 weeks. Colonies that shapes and different colors isolated. Each colony is done purification by means of scraping 1 ose colonies a zigzag direction on a petri dish containing media $100 \%$ marine so then incubated at $30{ }^{\circ} \mathrm{C}$ for $1-2$ days. After the new colony grew and then re etching performed on $100 \%$ marine media in order to obtain a single colony.

Enrichment method by distributing the liquid culture medium to $100 \%$ marine order, made after 2 weeks of incubation, then the culture was incubated at $30{ }^{\circ} \mathrm{C}$ for one week and the number of colonies counted, isolated and purified. Storage of purified performed using $25 \%$ glycerol in the medium MA

\section{Characterization of the $16 \mathrm{~S}$ rRNA gene molecules}

PCR is an in vitro method to produce a number of specific DNA fragments with a length and a predetermined amount the squens of a small number of complex template, (Davis, 1994). Deocsiribosa Nucleic Acid (DNA) of pure isolates were extracted with Chelex method $20 \%$, and then carried through 35 cycles of PCR, denatured at $95^{\circ} \mathrm{C}, 1 \mathrm{~min}$, annealing at a temperature of $55{ }^{\circ} \mathrm{C}: 1 \mathrm{~min}$ and extension at $72{ }^{\circ} \mathrm{C}: 2$ minutes, incubated at $72{ }^{\circ} \mathrm{C}: 10$ minutes, (Alamri, 2010). DNA electrophoresis, PCR products with clear tape size of 150 bp. (Clarridge, 2004; Ramadhan et al., 2012)

DNA sequencing is done by sending to Macrogen, the sequencing results to the GenBank identified through BLAST (Basic
Local Alignment Search Tool), or a multiple alignment with GenBank under Bioedit program version 7.2.5. (Murayama et al., 2010)

\section{RESULTS AND DISCUSSION}

\section{Data sampling}

Supporting data observed when sampling sponge in Melawai Beach of Balikpapan is presented in Table 1, below:

Table1. Conditions Melawai Beach of Balikpapan as Water Sampling Points

\begin{tabular}{lc}
\hline \multicolumn{1}{c}{ The Parameter } & Value Measurement \\
\hline Coordinates & $01^{0} 16.36^{\prime} 8^{\prime \prime} \mathrm{LS}$ \\
sampling & $116^{0} 48.23^{\prime} 6^{\prime \prime} \mathrm{BT}$ \\
Temperature $\left({ }^{\circ} \mathrm{C}\right)$ & 29 \\
Salinity $(\mathrm{ppt})$ & $30 \% \mathrm{o}$ \\
$\mathrm{pH}$ & 7 \\
Depth of sampling & $2,7 \mathrm{~m}$ \\
\hline
\end{tabular}

Primary Data: Januari, 2014

Physical characteristics sponge samples directly observed in the field, beige brown, elongated shape partially clustered, have spicules form fibrous silicate and sponging. massiva sponge growth form and oscula scattered along the surface of the sponge body, skeleton irregular and contains spongin consists of the main part and stringy parts. Based on this it was concluded that the sponges are identified by species Callyspongia sp, family Callyspongiidae, class Demospongiae, (Duchassaing \& Michelotti, 1964 in Dactylia, 1885; Marzuki et al., 2014; Ismet et al., 2011; Thakur, 2004). 


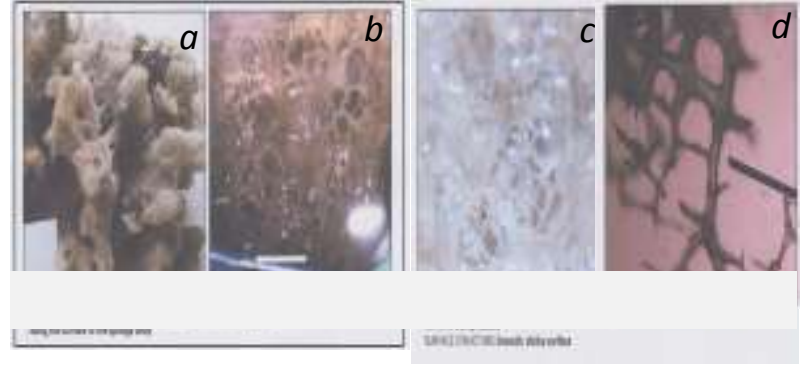

Figure 2. Results of analysis of the morphology of the sponge species Callyspongia sp., A) growth form massiva, oscula scattered along the surface of the sponge body; $b$ ) the results of staining with $\mathrm{EtOH}$; c) the results compress texture; d) megascleres Axea be tangent with various sizes. (Primary Data, September 2014).

These results are in accordance conclusion, Ruppert et al., 2004; Gazave, 2010; Ismet et al., 2011, which states that the structure of the sponge at least have skeleton contain debris or spicules and spongin, sponge cells and possibly some micro-symbionts.

\section{Results Isolation and purification of bacterial symbionts sponge of Callyspongia sp.}

Bacterial colonies were isolated and purification is growing colonies dominant. Both colonies identified can grow well in dilution $10^{-2} \mathrm{~s} / \mathrm{d} 10^{-4}$.

Macroscopic identification and purifica-tion of the isolated sponge Callyspongia sp. obtained only two isolates. The first isolates with characteristics of large round shape and creamy-white, hereinafter referred isolates 1 , and isolates both the characteristics of the jagged shape, elongated, brownish white, hereinafter referred to isolate 2, (Hooper, 1997; Mapstone, 1990).

The results of the isolation and purification of bacterial symbionts obtained only two isolates, it is reasonable and consistent with the observation of cell biomass was dominated by the skeleton (spicules and cell debris), then the cell sponge and a little pellet of bacteria as well as morphological observation Callyspongia sp of sponge, (Silberhorn et al., 2007; Ismet et al., 2011; Murniasih et al., 2010; Marzuki et al., 2014)

\section{Molecular characterization of genes $16 \mathrm{~S}$ rRNA isolate Micro symbionts}

There are four stages of DNA isolation, first. cell solution; the second. DNA extraction; the third. DNA precipitation; and fourth. DNA leaching.
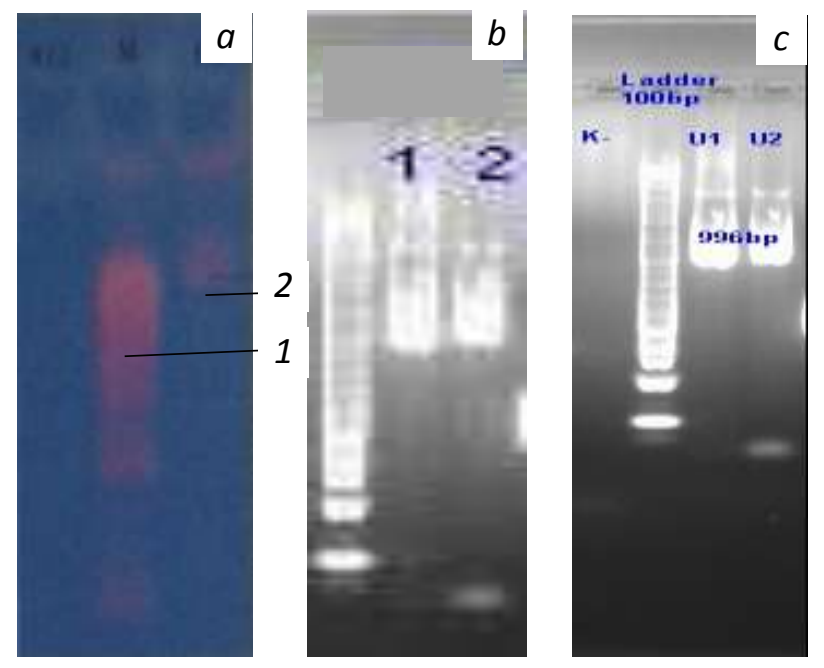

Figure 3. a) Results Genomic DNA isolation, number 1 genome comparison. 2 Genome number of samples; b) the results of genome amplification, the number is 1 estimates base pair (bp) isolates 1 and number 2 isolates 2; c) Results of amplification after purification with an estimated 996 bp bacterial symbionts sponge of Callyspongia sp, Primary Data, November 2014.

PCR with 16S rRNA gene sequencing allows the identification of bacteria is more accurate than those obtained by testing the phenotype. Analysis of 16S rRNA allows the discovery of new pathogens, as it can identify the bacteria that can not be cultured, (Samaila et al., 2014). 

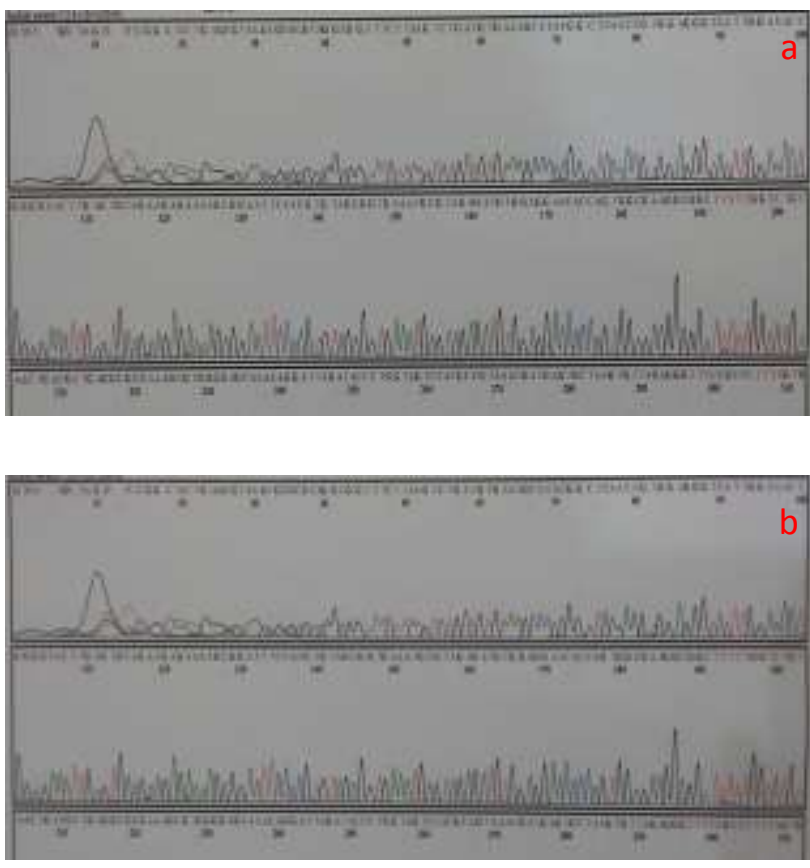

Figure 4. Chromatogram pieces of DNA sequences of bacterial symbionts Callyspongia $\mathrm{sp}$ isolates, a) isolate one piece of 17-230 bp sequences, b) Isolate 2 pieces of $10-205 \mathrm{bp}$ sequence

Sequencing results obtained in the form of raw data, then processed using the software program Bioedit version 7.2.5. Data that has been processed by the program Bioedit used as baseline data to be processed back to the multiple alignment (multiple alignment) with the database. Universal 16S rRNA gene in bacteria, in general comparison of $16 \mathrm{~S}$ rRNA sequences, (Clarridge, 2004).

Sequencing was opened through Bioedit program, then the bacterial DNA sequences inserted into the Basic Local Alignment program Search Tool, (http: //blast.ncbi. Nlm. nih.gov/Blast. Cgi), sequences identified by GenBank DNA database on the site, (Samaila et al., 2014; Clarridge, 2004).
Table 2 Results of BLAST (Basic Local Alignment Search Tool) the Micro symbionts of sponge

\begin{tabular}{|c|c|c|c|c|}
\hline $\begin{array}{c}\text { Sample } \\
\text { code }\end{array}$ & $\begin{array}{c}\text { Sample } \\
\text { Sequences }\end{array}$ & $\begin{array}{c}\text { Sequences } \\
\text { GenBank }\end{array}$ & $\begin{array}{c}\text { percent } \\
\text { homologous } \\
(\%)\end{array}$ & Species \\
\hline $\begin{array}{c}\text { Isolate } \\
1\end{array}$ & $17-916$ & 554-1461 & $\begin{array}{c}817 / 913 \\
(89 \%)\end{array}$ & $\begin{array}{l}\text { Bacillus } \\
\text { subtilis }\end{array}$ \\
\hline $\begin{array}{c}\text { Isolate } \\
2\end{array}$ & $10-960$ & $19-968$ & $\begin{array}{c}948 / 952 \\
(99 \%)\end{array}$ & $\begin{array}{l}\text { Bacillus } \\
\text { flexus }\end{array}$ \\
\hline
\end{tabular}

DNA sequence analysis of the sample sequences of isolates 1 on a stretch of nucleotides $17-916$ or $899 \mathrm{bp}$, with details of the purine group consisting of $28.44 \%$ Guanine, $24.27 \%$ Adenine and pyrimidine group consisting of $25.10 \%$ Cytosine, $21.15 \%$ Thymine and there is a row of $1.04 \%$ non pairs of nucleotides. These isolates have the same genus high reached $89 \%$ homologous to the alignment of multiple sequences of GenBank at 5541461 bp stretch. Then identified Bacillus subtilis strain BAB-684. Previously been conducted identifying Basillus subtilis PCR method at $\pm 800 \mathrm{bp}$, (Ling Xu et al., 2012; Ramadhan et al., 2012).

While the sequence of the DNA sequences of isolates 2 on the stretch of nucleotides $10-960$ or $950 \mathrm{bp}$, with details of the purine group, consisting of $30.62 \%$ Guanine, $25.46 \%$ Adenine and pyrimidine group consisting of $22.58 \%$ Cytosine, $20.31 \%$ Thymine and there is a row of $1.03 \%$ non pairs of nucleotides. These isolates have the same genus high reached $99 \%$ homologous to multiple sequence alignments on a stretch of 19-968 bp GenBank identified Bacillus flexus strain PHCDB20. Previously been done identification of Basillus flexus PCR method to $\pm 1,000 \mathrm{bp}$, (Alamri, 2012). Both of these species is the genus Bacillus, family Bacillaceae and Bacilli class. Character of a bacterium is determined by the composition of the constituent DNA and be decisive in the performance of hydrocarbon degrading bacteria, (Ling $\mathrm{Xu}$ et al., 2012). 
The molecular structure of deoxyribose nucleotide acid constituent components can be seen in Figure 5.

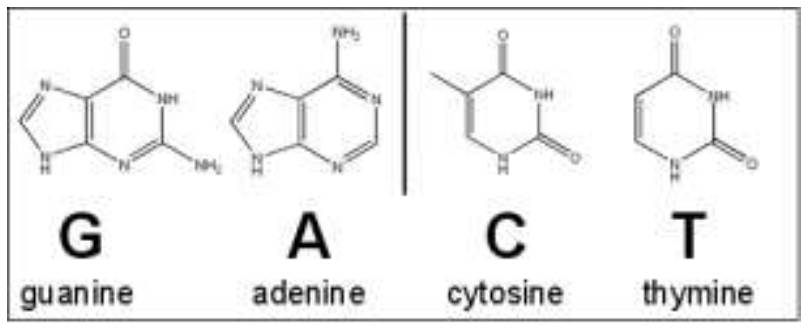

Figure 5.The structure of the DNA molecule

BLAST results that achieve a high degree of similarity genus when reaching over $80 \%$ homologous, (Ramadan et al., 2012). Identification by PCR and DNA sequencing of bacteria through the BLAST program is more convincing as compared with bacterial DNA data in GenBank which contains tens of millions of existing bacterial DNA data, (Samaila et al. 2014).

These results provide a strong belief that these two species is the genus Bacillus, are known to carry out chemical reactions solving hydrocarbon molecules, (Teng et al., 2010; Gan et al., 2009; Aliyanta et al., 2011; Syakti et al., 2013), so it is natural that the Callyspongia sp symbioning sponges with Basillus subtilis and Basillus flexus viable and capable of adjusting to the hydrocarbon contaminated environments such as in Melawai Beach, Balikpapan, East Kalimantan

\section{CONCLUSION}

Conclusions of research on the molecular characterization of the 16S rRNA gene micro symbiont of sponge origin waste hydrocarbon contaminated areas in Melawai Beach, Balikpapan, East Kalimantan, is the histo-morphological analysis obtained sponge with species of Callyspongia sp. The results of the isolation and purification of micro symbionts of sponge obtained 2 (two) isolates. Characteristics of Isolates 1, globular, colonize and creamy, while isolates 2, jagged shape, oval and white colonies. While the results of the molecular characterization of the 16S rRNA gene by PCR using primers FP-U1 (5'-CGCCAGCAGCCGCGGTAATA-3') at nucleoti-des 518-537, and RP-U2 (5'ATCGG $(\mathrm{C} / \mathrm{T})$ TACCTTGTTACGACTTC- 3 '), to isolate one is bacteria species of bacillus subtilis strain BAB-684 the number of nucleotide pairs reached 899 bp and the degree of similarity in GenBank reached $89 \%$ homologous, while the isolates 2 are species of bacillus flexus strain PHCDB20 the number reached 950 bp nucleotide pairs with the degree of similarity in GenBank reached 99\% homologous. Both species are micro symbiont of sponge Callyspongia sp obtained from hydrocarbon contaminated environments showed that the sponge and symbiotic bacteria capable of living and can degrade hydrocarbon waste.

\section{REFERENCES}

[1] Gan, S., E.V. Lau, H.K. Ng., 2009. Remediation of Soils Contaminated with Polycyclic Aromatic Hydrocarbons (PAHs), Journal of Hazardous Materials, 172 : 532-549

[2] Clarridge, Jill E. 2004. Impact of $16 \mathrm{~S}$ rRNA Gene Sequence Analysis for Identification of Bacteria on Clinical Microbiology and Infectious Diseases. Journal Clin Microbiol; 17(4): 840862

[3] Ismet, S.M., Soedharma, D., Effendi, H., 2011. Morphology and cell biomass of sponge Aaptos aaptos and Petrosia sp. Journal Ilmu dan Teknologi Kelautan Tropis. Vol. 3 No. 2, p. 153-161

[4] Ramadhan L.M., Buwono D.I., Mulyani Y.,. 2012. Analysis of potensial and molecular characterization of $16 \mathrm{~S}$ rRNA gene of isolation cellulolytic bacteria from Eucheuma sp. and Sargassum sp. Macroalgal as a producer of cellulose enzymes, Journal. Perikanan dan Kelautan, Vol. 3, No. 3:61-67. 
[5] Samaila A., Massi N., Sjahril R., 2014. Identification Bacteria in Air Intensive Care Unit (ICU) Wahidin Sudirohusodo Hospital, Journal "dr. Aloei Saboe", Vol.1 No. 2:23-28

[6] Syakti, D. A., Yani, M., Hidayati, V.N., Siregar, S.A. Doumeng, P., I.M. Sudiana, M., 2013. The Bioremediation potential of hydrocarbonoclastic bacteria isolated from a Mangrove Contaminated by Petroleum Hydrocarbons on the Cilacap Coast, Indonesia. Journal Bioremediation, Vol. 17(1):11-20, ISSN: 1088-9868 online. DOI: 10.1080 .731446

[7] Alamri A. Saad, 2010. Isolation, phylogeny and characterrization of new $\alpha$-amylase producing thermophilic Bacillus sp. from the Jazan region, Saudi Arabia. Int. Journal Biochem. Biotech. 6:537-547.

[8] Aliyanta, B., Sumarlin O.L., Mujab S.A., 2011. Penggunaan Biokompos dalam Bioremediasi Lahan Tercemar Limbah Minyak Bumi, Jurnal Valensi, 2011, Vol. 2 No.3:430-442

[9] Marzuki, I., Noor, A., Djide, N.M., La Nafie, N., 2014. Isolation and Identification on Degradator Bacterial of Petroleum waste which Symbionts with Sponge Callyspongis sp from Melawai Beach. Prosiding: International Confrence on the sciences (ICOS), 19-20 Nopember 2014, Makassar, ISBN : 9786027219809, p. 493-503

[10] Hooper, J.N,A., 1997. Guide to sponge collection and identification. Version Merch. Queensland Museum South Brisbane, Journal Queensland, Australia, 26-29

[11] Jayardana, Trigunawan, 2006. Penilaian Terpadu Dampak Tumpahan Minyak Di Perairan Balikpapan : Studi Kasus Tumpahan Sludge Oil Dari Kapal Mt. panos, Tesis UI.

[12] Murniasih, T., Rasyid, A., 2010. Potensi bakteri yang berasosiasi dengan spons asal Barrang Lompo, Makassar sebagai sumber bahan antibakteri. Journal
Oseanologi dan Limnologi di Indonesia, 36(3):281-292

[13]Teng, Ying, Yongming Luo, Mingming Sun, Zengjun Liu, Zhengao Li, Peter Christie, 2010. Effect of bioaugmentation by paracoccus sp. strain HPD-2 on the soil microbial community and removal of polycyclic aromatic hydrocarbons from an aged contaminated soil. Journal Bioresource Technology. 101:34373443

[14]Thakur, NL., and Weg Muller, 2004. Biotechnological Potensial of Marine Sponges. Jounal Current Science: (11) 86

[15] Ling Xu, Yang Cao, Xiang-Tian, De-fa Deng, Li-Na Xu and Zhen-Yu Liu, 2012. Molecular detection of tas A qene in endophytic bacillus species and characterization of the gene in Bacillus amylolique faciens. African Journal of Biotechnology. Vol. 11(23):6212-6219

[16] Silberhorn, A.M., V.Thiell and J.F. Imhoff, 2007. Abudance and bioactivity of cultured sponge associated bacteria from the Mediterranean Sea. Journal Microbial Ecology, 55:94-106

[17] Alamri, A. Saad, 2012. Biodegradation of microcystin-RR by Bacillus flexus isolated from a Saudi freshwater lake. Published online- doi:10.1016/j .sjbs.2012.06.006. Saudi Journal Biol Sci.; 19(4): 435-440

[18] Avecedo, Francisca, Lecticia, Pizzul, Maria, del Pilar Castilloc, Raphael, Cuevas, Maria, Cristina Diez, 2011. Degradation of Polyciclic aromatic hydrocarbons by the Chilean white-rot fungus Anthracophyllum discolor. Journal of Hazardous Materials, 185:212-219

[19]Dactylia Carter, 1885, The Callyspongiidae are a demosponge family in the; Callyspongia Duchassaing \& Michelotti, 1864 Callyspongiidae-Wikipedia, the free 
encyclo-pedia,en.wikipedia.org/ wiki/ Callyspongii dae, www.nova.edul ncri/soflaspongeguide/ sp_3.html

[20] Davis, L., M. Kuehl, \& J. Battey. 1994. Basic methods: Molecular biology. 2nd ed. Appleton \& Lange, Norwola: xii + $777 \mathrm{hlm}$

[21]Ekpo dan Udofia, 2008. Rate of biodegradation of crude oil by microorganism isolate from oil sludge environment. African journal of biotechnology, Vol.7 (24)

[22] Gazave E., 2010. filogeni molekuler mengembalikan subdivisi supra-generik spons homoscleromorph (Porifera, homosclero-morpha). PLoS One. 2010 Dec 14; 5 (12): e14290. doi : 10.1371/journal .pone .0014290

[23] Kim, T.K., Hewavitharana, A.K., Shaw, P.N., and Fuerst, J.A., 2006. Discovery of a new source of rifamycin antibiotics in marine sponge actinobacteria by phylogenetic prediction. Journal Appl. Environ. Microbiol., Vol. 72: 2118-2125

[24] Kozloff EN., 1990. Invertebrates. Saunders College Publishing, page 7392

[25] Mahdiyah, D., Wahyudi, T. A., Mukti, H. B., 2012. Isolasi bakteri yang berasosiasi dengan spons Jaspis sp. penghasil Enzim Protease. Jurnal Bioscientiae, 2012, Vol. 9 (1) :1-7

[26] Mapstone, G.M.,1990. Reef coral and sponges of Indonesia a video-based learning module. Printed by United Nations Education, Scientific and Cultural Organization, Paris France: 1020

[27] Murayama M, et al. 2010. Molecular identification of airborne bacteria associated with aerial spraying of bovine slurry waste employing $16 \mathrm{~S}$ rRNA gene PCR and gene sequencing techniques. Pubmed/20018377.

[28] Murniasih. T., Yopi dan Budiawan. 2009. Biodegradasi Fenantrena oleh Bakteri Laut Pseudomonas sp KalP3b22 asal Kumai Kalimantan Tengah. Jurnal Makara, Sains, Vol. 13 No1: 77- 80
[29] Ruppert, E.E., Fox, R.S., and Barnes, R.D., 2004. Invertebrate Zoology (7 ed.). Brooks / Cole. hlm 76-97. ISBN 0-03-025982-7

[30] Steindler, L., S. Beer, M. Ilan, 2002. Photosymbiosis in intertidal and subtidal tropical sponges. Symbiosis, Balaban Philadelphia, 33:1-11

[31]Wahl, M., Jensen, P.R., Fenical, W., 1994. Chemical control of bacterial epibiosis on Ascidians. Journal Mar. Ecol. Prog. Ser., Vol. 110: 45-57

[32] Wu, Yucheng, Ying Teng, Zhengao Li, Xuewei Liao, Yongming Luo, 2008. Potential role of polycyclic aromatic hydrocarbons (PAHs) oxidation by fungal laccase in the remediation of an aged contaminated soil. Journal Soil Biology \& Biochemistry, 40: 789-796

[33] Yani M. Dan Akbar Y. 2012. Diesel oil biodegradation process by mixed culture of hydrocarbon degrader bacteria. Jurnal Teknologi Industri Pertanian, Vol. 19 (1): 40-44

[34] Zarilla, K.A. and J.J. Perry. 1987. Bacillus thermoleovorans, sp. nov., a species of obligately thermophilic hydrocarbon utilizingendosporeforming bacteria. Journal Systematic and Applied Microbiology, Vol. 9: 247-255 